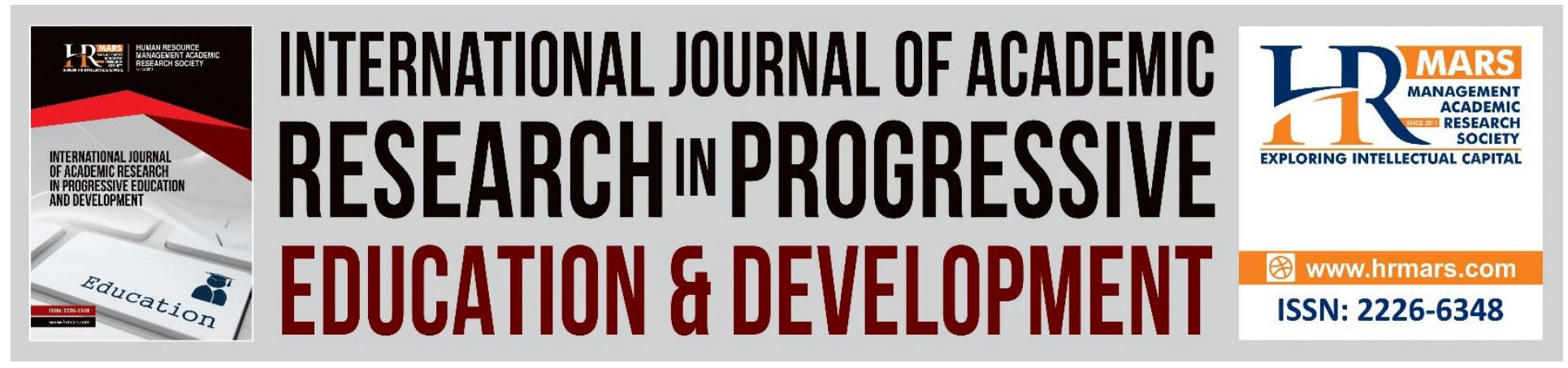

\title{
A Systematic Literature Review on the use of Mobile-assisted Language Learning (MALL) for Enhancing Speaking Skills among ESL and EFL Learners
}

Thirumangai Rajendran and Melor Md Yunus

To Link this Article: http://dx.doi.org/10.6007/IJARPED/v10-i1/8939

DOI:10.6007/IJARPED/v10-i1/8939

Received: 13 January 2021, Revised: 10 February 2021, Accepted: 27 February 2021

Published Online: 23 March 2021

In-Text Citation: (Rajendran \& Yunus, 2021)

To Cite this Article: Rajendran, T., \& Yunus, M. M. (2021). A Systematic Literature Review on the use of Mobileassisted Language Learning (MALL) for Enhancing Speaking Skills among ESL and EFL Learners. International Journal of Academic Research in Progressive Education and Development, 10(1), 586-609.

Copyright: (C) 2021 The Author(s)

Published by Human Resource Management Academic Research Society (www.hrmars.com)

This article is published under the Creative Commons Attribution (CC BY 4.0) license. Anyone may reproduce, distribute, translate and create derivative works of this article (for both commercial and non-commercial purposes), subject to full attribution to the original publication and authors. The full terms of this license may be seen at: http://creativecommons.org/licences/by/4.0/legalcode

Vol. 10(1) 2021, Pg. 586 - 609

http://hrmars.com/index.php/pages/detail/IJARPED

JOURNAL HOMEPAGE

Full Terms \& Conditions of access and use can be found at

http://hrmars.com/index.php/pages/detail/publication-ethics 


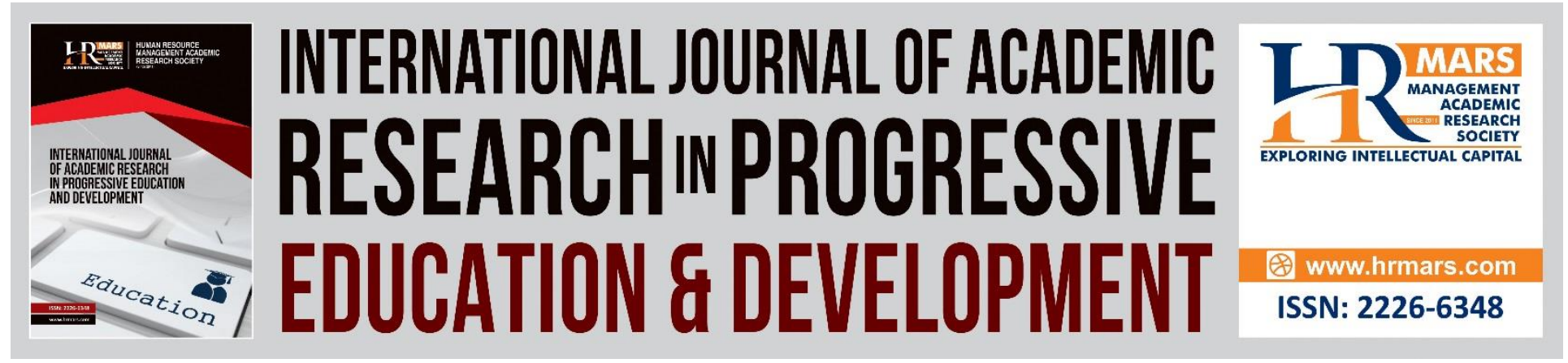

\title{
A Systematic Literature Review on the use of Mobile-assisted Language Learning (MALL) for Enhancing Speaking Skills among ESL and EFL Learners
}

\author{
Thirumangai Rajendran a and Melor Md Yunus ${ }^{b}$ \\ aFaculty of Education, Universiti Kebangsaan Malaysia, Selangor, Malaysia, baculty of \\ Education, Universiti Kebangsaan Malaysia, Selangor, Malaysia \\ Email: thirumangai2093@gmail.com
}

\begin{abstract}
Mastering all the four language skills has been the topmost priority among both ESL and EFL learners all over the world. Apparently, speaking skills remains to be the most challenging among other skills in which many learners are still struggling to speak proficiently. Past studies suggest that Mobile-assisted language learning (MALL) could be applied as a potential instructional approach in the pursuit of helping learners to gain speaking proficiency. However, there are limited reviews done on current studies which indicate the effectiveness of MALL for speaking particularly in ESL and EFL contexts. Hence, this paper sought to fulfill the gap by presenting a systematic review of relevant published studies done in MALL environments to enhance ESL and EFL learners' speaking skills from the year 2016 to 2020. The findings of the review suggest that the application of MALL propagates the concepts of the constructivism theory, promotes stressfree environment, supports situated learning, and provides ease of use. Further analysis indicate that mobile devices' general built-in features and mobile applications could be used as possible tools in helping learners to enhance their speaking skills in MALL environments. However, most of the reviewed studies' focus on tertiary education has created a literature gap. Thus, there is a need to study the implementation of MALL in both primary and secondary schools so that it could be benefited by ESL and EFL learners of all ages particularly in developing speaking skills.

Keywords: Mobile-assisted Language Learning (MALL), Language Skills, Speaking Skills, ESL, EFL

\section{Introduction}

The need to be proficient in all four English language skills has been given continuous emphasis and made as the topmost priority around the world due to the current demands of the $21^{\text {st }}$ century skills. Every individual is expected to master all the language skills to be distinguished
\end{abstract}


Vol. 10, No. 1, 2021, E-ISSN: 2226-6348 @ 2021 HRMARS

as a 'global player' and not being left out. Correspondingly, Rao (2019) opined that there has been growing concerns in the education system worldwide particularly in countries which regard English as a Second Language (ESL) and English as a Foreign Language (EFL) whereby multiple efforts are being taken to master the language skills. Regardless of that, speaking which is perceived to be the most important skill (Richards, 2008) remains to be the most challenging skill to be acquired among other language skills (Bailey \& Savage, 1994) and even more strenuous for many ESL and EFL learners worldwide (Leong \& Ahmadi, 2017; Abugohar et al., 2019; Paneerselvam \& Mohamad, 2019). Abugohar et al. (2019) further asserted that EFL learners tend to label their inability to speak proficiently as a true failure for them in language learning. Moreover, speaking skills are regarded significant for ESL and EFL learners' future career path (Rao, 2019) as the inability to communicate in English is one of the main reasons for unemployment. For this reason, the mastery of speaking skills is made crucial for both ESL and EFL learners and there appears a need to review on suitable pedagogical methods, techniques and approaches which could elucidate educators on how the teaching and learning of speaking could be made fruitful.

The rapid advancement in technology in this globalised era has influenced the instructional processes and myriads of technologies have been used to enhance the acquisition of speaking skills among ESL and EFL learners. One of the areas that has significantly indicated positive outcomes is Mobile-assisted Language Learning (MALL). MALL broadly refers to learning language anytime, anywhere whereby language activities are conducted through mobile devices without being restricted by physical location or a determined time (Traxler \& Kukulska, 2016). Mobile devices include portable and personal handheld devices such as laptops, personal digital assistants (PDA), tablets, smart phones, and mobile phones and they make learning easier for learners (Hashim et al., 2017). Sharples (2009) claimed that mobile devices are suitable for modern education and in fact, their ubiquitous feature has resulted MALL to be widely advocated in the educational context worldwide (Traxler \& Kukulska-Hulme, 2015; Kukulska-Hulme et al., 2017). As a matter of fact, past studies indicate that MALL has helped enhancing learners' speaking skills in remarkable ways (Darmi \& Albion, 2017; Kusmaryani et al., 2019; Nanjundan et al., 2020).

Nevertheless, there is a paucity of systematic reviews done on recent studies to shed some light on how MALL could offer plausible ways in enhancing learners' speaking skills especially in the ESL and EFL contexts. Several systematic reviews examined language learning in MALL by reviewing studies conducted over the period from 1993 to 2016 (Burston, 2015; Sung et al., 2016; Persson \& Nouri, 2018). However, to the researchers' best knowledge, review done specifically on studies investigating MALL for the development of speaking skills among ESL and EFL learners from the year 2016 to 2020 is still scarce. Therefore, the current systematic review aims to fill in the literature gap by synthesising the findings of past studies conducted to enhance ESL and EFL learners' speaking skills in MALL environments from the year 2016 to 2020. Besides, the review intends to highlight possible mobile device tools that could be used for the teaching and learning of speaking. This study employs a mixed-method systematic review approach in which studies from different research traditions but focused on the same topic were combined to generate evidence to guide decision-making (Pearson et al., 2013). It is also regarded as a process of conducting comprehensive analysis of two or more types of data (e.g. quantitative and 
qualitative) and then synthesised into a final and combined single primary synthesis being qualitative and quantitative (The Joanna Briggs Institute, 2014).

This systematic literature review (SLR) aims to analyse and synthesise research articles on MALL for speaking among ESL and EFL learners between the years 2016 to 2020 and sythesise their findings to meet the proposed objectives: 1) to understand the pedagogical approaches offered by MALL in the teaching and learning of speaking skills among ESL and EFL learners and 2) to discover potential mobile device tools that could be used in enhancing speaking skills among ESL and EFL learners.

There are two research questions that have been outlined to direct the SLR and they are:

1. What are the pedagogical approaches offered by MALL in the teaching and learning of speaking skills among ESL and EFL learners?

2. What are the potential mobile device tools that could be used in enhancing speaking skills among ESL and EFL learners?

\section{Speaking Skills}

Speaking, as a productive skill, is very complex and requires the use of multiple abilities at the same time, which often develop at different rates. According to Harris (1969), there are five components in relation to speaking skills which are grammar, vocabulary, pronunciation, fluency, and comprehension. These components are generated based on two main aspects of speaking skills: accuracy and fluency. The ability to carry on a conversation by speaking the language competently is almost always set as a benchmark of successful acquisition of a particular language (Nunan, 1999; Brown, 2001; Burkart \& Sheppard, 2004). This further substantiates the reason for speaking skills been given the topmost priority in ESL and EFL contexts (Richards, 2008).

\section{Importance of Speaking Skills among ESL and EFL Learners}

The significance of speaking is identified with the integration of the other language skills. Leong and Ahmadi (2017) opine that speaking which helps learners to develop their vocabulary and grammar will eventually make them better writers. Learners who can express their ideas, tell stories, talk, and discuss verbally will be able to pen down their thoughts with less hassles. The idea that people learn how to speak before learning how to read has been accepted for a long time and now, it is believed that both speaking and reading skills have reciprocal relationship (Richards, 2008). In other words, as speaking skills increase, so does the reading skills. Speaking skills are also examined by Krashen (1988) to have strong relation with listening skills. He stated that when learners speak, they provide evidence that they have acquired the language through successful listening.

Other than that, good speaking skills can nurture the process of socialisation (Lucanus, 2017). Socialisation takes place when one puts a message together, communicate the message and interact with other people. Paneerselvam and Mohamad (2019) view 'social skills' as an advantage as it connects one with another. In relation to the $21^{\text {st }}$ century skills, they have further explained that social skills will enable people to work collaboratively, to solve problems, think critically and communicate effectively. These are some among those qualities expected to be possessed by employees in today's globalised world. Supporting this, Rao (2019) stated that 
having good communication is the passport to get better employment opportunities. Hence, it is apparent that speaking skills play a vital role among ESL and EFL learners and they need to be adequately prepared with good speaking skill so that they can compete as a 'global player' in various aspects of life.

\section{The Concept of MALL}

Trifonova and Ronchetti (2003) explain mobile learning as using Information Technology (IT) in enhancing teaching and learning experience through mobile devices. Thus, MALL could be referred as the use of diversified mobile technologies as assistance to expedite language acquisition. Naismith et al. (2004) identify two dimensions of mobile technologies: 1) personal and shared, and 2) portable and static. Past studies suggested that the use of mobile technologies in learning applies six learning theories namely constructivism, behaviorism, collaboration, situated, informal learning and lifelong learning, and support in teaching and learning (Naismith et al., 2004; Rahamat et al., 2017; Cakmak, 2019).

Traxler and Kukulska-Hulme (2015) claimed that MALL has been advocated by many teachers and a review done by Hashim et al. (2017) proven that MALL has developed over the past decade as a field within its own right, with an increasing number of articles that examine the use of mobile devices in both formal and informal language learning. They are discovered to provide richer learning content by extending learners' learning environment beyond the classroom setting (Kukulska, 2009). MALL environments are added more values by the unique attributes of mobile devices identified by Klopfer et al. (2002):

- Portability: the mobile devices allow movability

- Social interactivity: the mobile devices facilitate and enhance communication between users

- Context sensitivity: the mobile devices provide real data in learners' location, environment, and time

- Connectivity: the devices can be connected to each other or a shared network

- Individuality: the devices allow individual learning

These attributes make learning possible without being bounded by physical location and time as well as embrace the self-learning concept which promotes autonomy among learners.

\section{Application of MALL in ESL and EFL Contexts}

Keeping abreast of MALL affordances that have made language learning attainable through the mentioned attributes, numerous studies have investigated its efficacy in ESL and EFL learning contexts. The ubiquity of mobile devices allows a group of Iranian EFL learners involved in Foomani \& Hedayati's (2016) study to be indulged in limitless learning opportunities in everyday life experiences as well as virtual spaces which promotes autonomous learning. Similarly, Ali et al. (2019) reported that a group of Pakistani EFL learners were able to carry out learning flexibly as they could perform learning anywhere at any time. This further allows learners to control their own learning with more empowerment (Kukulska Hulme \& Shield, 2008).

Other than that, MALL is believed to maintain learners' interest, increase engagement, and increase their motivation in learning (Khan \& Islam, 2019). Besides, they connoted that learners could communicate among teacher and peers in a collaborative situation as they discuss 
and share feedbacks in learning language skills. In addition, the connectivity of MALL offers ESL learners with opportunities to communicate with native speakers and speakers from other countries (Hashim et al., 2017). Octavia et al. (2019) claimed that mobile devices provide authentic materials which are more accessible than those in conventional teaching settings.

Past studies imply that MALL facilitates the acquisition of language skills and linguistic knowledge in second and foreign language learning. A study conducted by John and Yunus (2019) investigated the use of different writing mobile apps and learners' writing performance has significantly improved as they were able to learn with enjoyment, ease, and interest. A review on English learning mobile apps by Gangaiamaran and Pasupathi (2017) suggested a list of mobile apps for primary, secondary, and tertiary learners as being helpful in enhancing listening, speaking, reading, and writing skills. Mobile apps are believed to be authentic, exciting, and joyful for learners. A recent study by Supti (2019) MALL through mobile phones as a great platform for collaborative learning, vocabulary acquisition, reading and writing skills improvement through text messaging. Learning is no longer confined to a specific space and time due to MALL's versatility.

Nonetheless, several studies examined the acceptance of MALL for language learning among ESL learners (Soleimani et al., 2014; Azli et al., 2018) and EFL learners (Chung et al., 2015; Hsieh et al., 2017; Gamble, 2018) signified that MALL has been positively accepted among learners as the use of mobile devices is perceived to be both useful and easy for language learning. The studies further conveyed that learners' positive acceptance of MALL influences their attitude and behaviour to continue using mobile devices for learning purposes.

\section{Method}

In order to produce an unbiased and extensive set of findings, systematic reviews make use of a broad search strategy in order to guide the inclusion and exclusion criteria of a review. A systematic review is regarded as a piece of research guided by an explicit and transparent set of methods and stages with the potential to be replicated and updated (EPPI, 2016). In this study, systematic reviews of literatures were done by searching articles from two prominent databases namely Google Scholar and Educational Resources Information Center (ERIC). As for the phases of the review, five-steps of conducting a systematic review proposed by Khan et al. (2003) was employed as shown in Figure 1 below.

Figure 1.The five phases of systematic literature review proposed by Khan et al. (2003)

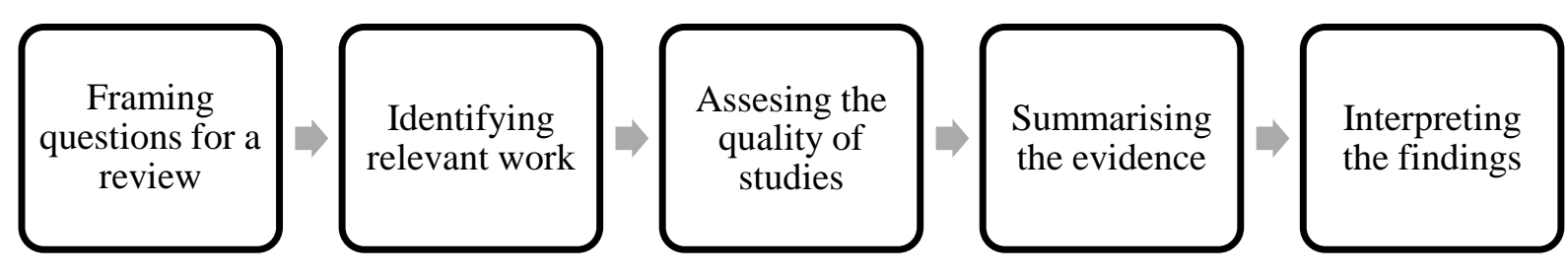

Phase 1: Framing questions for a review 
Recently, the demand on improving speaking skills among ESL and EFL learners has lead educators around the world to study the incorporation of MALL in the teaching and learning of speaking worldwide. However, limited reviews were done on these studies to understand how MALL environments could possibly help in enhancing learners' speaking skills. Therefore, this paper aims to review the articles published on this area from the year 2016 to 2020 . The study is directed by two research questions and they are a) What are the pedagogical approaches offered by MALL in the teaching and learning of speaking skills among ESL and EFL learners? and b) What are the potential mobile device tools that could be used in enhancing speaking skills among ESL and EFL learners?

\section{Phase 2: Identifying relevant work}

As the second phase of the study, the researcher has identified relevant work which provided meaningful and useful information to meet the objectives of the review. As the initial step, the researcher has gathered 35 relevant articles by searching in electronic databases. In reducing the risk of biasness, a more extensive scope of searching was done based on the reference lists provided by some selected articles. Since studies done on the use of mobile learning to enhance speaking skill among ESL learners alone was apparently limited, the context of EFL was included to provide richer content for the review. This review has included conference proceedings articles based on empirical evidence besides full-text articles and peer-reviewed journal articles. They were obtained from electronic data bases such as general internet search engine, Google Scholar and ERIC. Google Scholar and ERIC provide rich information in the discipline of education (Kaliisa \& Picard, 2017) under which the study belongs. Therefore, both Google Scholar and ERIC were deemed to be most appropriate to be used in this review in achieving the objectives.

\section{Phase 3: Assessing the quality of studies}

In order to ensure the quality of this review, the articles searched were analysed based on the inclusion and exclusion criteria adopted and adapted from systematic reviews done by Kaliisa and Picard (2017) and Zakaria et al. (2019). Articles chosen for this review were ensured to have met both the inclusion and exclusion criteria as stated in Table 1 below. 
Vol. 10, No. 1, 2021, E-ISSN: 2226-6348 @ 2021 HRMARS

Table 1. Inclusion and exclusion criteria for this systematic review

\begin{tabular}{|c|c|c|}
\hline Criterion & Inclusion criterion & Exclusion criterion \\
\hline Focus of study & Uses mobile technologies & Does not use mobile technologies \\
\hline Devices & $\begin{array}{l}\text { Smart phones, iPads, tablets, } \\
\text { MP3 players and other } \\
\text { handheld devices. }\end{array}$ & $\begin{array}{l}\text { Computers and other non- } \\
\text { handheld devices. }\end{array}$ \\
\hline Features & $\begin{array}{l}\text { Must have used in built } \\
\text { features of mobile phone or } \\
\text { other available features }\end{array}$ & $\begin{array}{l}\text { None of the mobile features is } \\
\text { used }\end{array}$ \\
\hline Field of study & $\begin{array}{l}\text { MALL must be implemented in } \\
\text { the education field. }\end{array}$ & $\begin{array}{l}\text { MALL is not implemented in the } \\
\text { education field. }\end{array}$ \\
\hline Language skill & $\begin{array}{l}\text { Speaking skill or other skills } \\
\text { with inclusion of speaking skill }\end{array}$ & $\begin{array}{l}\text { Other than speaking skills- } \\
\text { listening, reading, writing }\end{array}$ \\
\hline Context of study & ESL or EFL learners & Native learners \\
\hline $\begin{array}{l}\text { Year of } \\
\text { publication }\end{array}$ & Published between 2016-2020 & $\begin{array}{l}\text { Not published between 2016- } \\
2020\end{array}$ \\
\hline
\end{tabular}

Both the inclusion and exclusion criteria are crucial in designing high quality research protocol (Zakaria et al., 2019). Hence, the inclusion and exclusion criteria were adhered closely to provide credible answers for the research questions.

\section{Phase 4: Summarising the Evidence}

The electronic databases used to search articles for this study are Google Scholar and ERIC. The keywords such as 'The use of mobile technologies to enhance speaking skill among ESL and EFL Learners', 'Mobile-assisted Language Learning to enhance speaking skill among ESL and EFL Learners' and 'Mobile learning for speaking among ESL and EFL learners' were entered in the search engine and the range of years was customised to be between 2016 to 2020.

The articles published within the year 2016 to 2020 in the first database, Google Scholar resulted in 11,250 articles in total. The articles were then filtered by focusing on the use of MALL particularly in 'speaking skills' and among ESL or EFL learners. Next, the use of mobile devices in the articles was strictly ensured to be 'handheld devices' such as smart phones, iPads, tablets and laptops. The filtration has remained 35 articles. The process is furthered by identifying only fulltext articles, conference proceedings with empirical evidence and peer-reviewed journal articles which has left 23 articles to be included in the final selection process.

As for the second database, ERIC, the initial search process has resulted in 147 articles in total. The articles were then filtered again by applying the same keywords used in Google Scholar. Likewise, only 10 journal articles, 3 conference-proceedings with empirical evidence and peerreviewed were considered appropriate. Hence, it has left the researcher with 13 articles in which 3 articles were removed as they do not provide full access of the texts. Therefore, there were only 10 articles left to be included in the final selection process for the review.

Finally, a total of 33 articles were gathered from Google Scholar as well as ERIC. After considering the inclusion and exclusion criteria of the review, 18 articles from the total were excluded and only 15 articles were selected to be the most appropriate for the analysis and 
Vol. 10, No. 1, 2021, E-ISSN: 2226-6348 @ 2021 HRMARS

synthesise of this systematic literature review as they have investigated MALL for speaking among ESL and EFL learners and provided empirical findings. Among them, 11 articles were from Google Scholar and 4 were from ERIC. Out of 15 shortlisted published articles, one article was published in 2016, two were published in 2017, ten were published in 2019 and two were published in 2020. The year 2019 marked the highest number of publications.

\section{Phase 5: Interpreting the findings}

The findings of the studies were analysed using mixed-method systematic review approach in which they are combined, and relevant themes were generated in order to answer the proposed research questions. Table 2 below shows the analysis done on the databases and methods used in the studies reviewed. From the table, it is evident that most of the studies adopted mixed method, followed by quantitative and qualitative. In terms of levels of education, most of the research settings were tertiary institutions meanwhile the rest were secondary and primary institutions as reviewed in Table 3.

Table 2.Analysis on the methods and levels of education used in the studies reviewed

\begin{tabular}{lcccc} 
Database & Quantitative & $\begin{array}{c}\text { Method } \\
\text { Qualitative }\end{array}$ & Mixed method & Total \\
\hline Google Scholar & 5 & 2 & 4 & 11 \\
\hline ERIC & 1 & 0 & 3 & 4 \\
\hline Total & 6 & 2 & 7 & 15 \\
\hline
\end{tabular}

Table 3. Analysis on the levels of education of the studies reviewed

\begin{tabular}{lcccc}
\hline Database & Primary & $\begin{array}{c}\text { Level of education } \\
\text { Secondary }\end{array}$ & Tertiary & Total \\
\hline Google Scholar & 1 & 1 & 9 & 11 \\
\hline ERIC & 1 & 1 & 2 & 4 \\
\hline Total & 2 & 2 & 11 & 15 \\
\hline
\end{tabular}

\section{Results}

From a systematic review of educational research published between 2016 to 2020 in MALL environments to enhance speaking skills among ESL and EFL learners, 15 articles were chosen to be the most appropriate and they formed the basis for answering the proposed research questions.

\section{RQ1: What are the pedagogical approaches offered by MALL in the teaching and learning of speaking skills among ESL and EFL learners?}

All the relevant articles were reviewed, and their findings were listed down. The findings were then synthesised to look for similar patterns. The synthesis of the results is summarised in Table 4 below. 
Vol. 10, No. 1, 2021, E-ISSN: 2226-6348 @ 2021 HRMARS

Table 4. Summary on the pedagogical approaches offered by MALL in the teaching and learning of speaking

\begin{tabular}{|c|c|c|c|}
\hline No & Article/ Study & $\begin{array}{c}\text { Participants \& } \\
\text { Context }\end{array}$ & $\begin{array}{c}\text { Results } \\
\text { (Pedagogical Approaches offered by MALL) }\end{array}$ \\
\hline 1 & $\begin{array}{l}\text { Moghaddas and } \\
\text { Bashirnezhad } \\
(2016)\end{array}$ & $\begin{array}{l}30 \text { Iranian EFL } \\
\text { learners at a } \\
\text { Language } \\
\text { Institute } \\
\text { (tertiary) } \\
\text { Iran }\end{array}$ & $\begin{array}{l}\text { The experimental group outperformed the } \\
\text { controlled group by having improved } \\
\text { speaking fluency through autonomous } \\
\text { learning, responsibility towards learning, and } \\
\text { joint social collaboration in line with ZPD. }\end{array}$ \\
\hline 2 & $\begin{array}{l}\text { Darmi and } \\
\text { Albion (2017) }\end{array}$ & $\begin{array}{l}76 \text { Malaysian } \\
\text { undergraduate } \\
\text { ESL learners at a } \\
\text { higher education } \\
\text { institution } \\
\text { (tertiary) } \\
\text { Malaysia }\end{array}$ & $\begin{array}{l}\text { The performance of learners in the } \\
\text { experimental group increased in terms of oral } \\
\text { communication skills. } \\
\text { Learners think, learn, and construct their own } \\
\text { knowledge through experience. } \\
\text { Social interaction that took place has } \\
\text { promoted collaborative learning. }\end{array}$ \\
\hline 3 & Sun et al. (2017) & $\begin{array}{l}\text { First grade } \\
\text { Chinese EFL } \\
\text { learners } \\
\text { (primary) } \\
\qquad \text { China }\end{array}$ & $\begin{array}{l}\text { The gain in English fluency was higher among } \\
\text { the learners in the experimental group } \\
\text { whereby they were able to speak with low- } \\
\text { stress and in situated contexts. } \\
\text { The use of Papa SNS is regarded to be an easy } \\
\text { means to practice speaking skills as it is user- } \\
\text { friendly. }\end{array}$ \\
\hline 4 & $\begin{array}{l}\text { Abugohar et al. } \\
\text { (2019) }\end{array}$ & $\begin{array}{l}49 \text { Arabian EFL } \\
\text { learners from } \\
\text { higher education } \\
\text { institutions } \\
\text { (tertiary) } \\
\text { Saudi Arabia }\end{array}$ & $\begin{array}{l}\text { Smartphone applications are regarded as a } \\
\text { good source of authentic materials, helping shy } \\
\text { anxious learners in less stressful teaching and } \\
\text { learning environment towards better fluency, } \\
\text { accuracy, and confidence. }\end{array}$ \\
\hline 5 & $\begin{array}{l}\text { Almarshadi et } \\
\text { al. (2019) }\end{array}$ & $\begin{array}{l}209 \quad \text { EFL } \\
\text { undergraduate } \\
\text { learners } \\
\text { (tertiary) } \\
\text { Saudi Arabia }\end{array}$ & $\begin{array}{l}\text { Learners believe that the use of M-learning } \\
\text { helps them in improving speaking skills in these } \\
\text { aspects: } \\
\text {-content delivery and creation } \\
\text { (learn words and phrases from authentic } \\
\text { materials) } \\
\text { - contextual learning } \\
\text { (improves pronunciation, grammar accuracy, } \\
\text { oral comprehension) } \\
\text { - supporting communication }\end{array}$ \\
\hline
\end{tabular}


(able to communicate with friends)

- encouraging personal engagement (building confidence and the ability to express thoughts in English)

\begin{tabular}{|c|c|c|c|}
\hline 6 & $\begin{array}{l}\text { Azlan et al. } \\
\text { (2019) }\end{array}$ & $\begin{array}{l}8 \text { participants; } 4 \\
\text { participants from } \\
\text { urban pre-school } \\
\text { in Selangor and } 4 \\
\text { participants from } \\
\text { rural primary } \\
\text { school } \\
\text { (primary) } \\
\text { Malaysia }\end{array}$ & $\begin{array}{l}\text { Majority of the learners acknowledged that } \\
\text { Instagram motivates and boosts their interest } \\
\text { to practice English speaking and at the same } \\
\text { time improve their speaking skills. Other } \\
\text { benefits of using Instagram include: } \\
\text { - creating a lively learning environment which } \\
\text { is interactive and engaging } \\
\text { - developing a strong learning collaboration } \\
\text { and active interaction between pupils and } \\
\text { teacher }\end{array}$ \\
\hline 7 & Gonulal (2019) & $\begin{array}{l}97 \text { EFL learners } \\
\text { (tertiary) } \\
42 \text { different } \\
\text { countries }\end{array}$ & $\begin{array}{l}\text { The use of Instagram platform as a tool in } \\
\text { MALL is seen to have potential in developing } \\
\text { all the language skills in general, and } \\
\text { vocabulary and communication skills. } \\
\text { It can serve as a bridge between formal and } \\
\text { informal language learning. }\end{array}$ \\
\hline 8 & $\begin{array}{l}\text { Kusmaryani et } \\
\text { al. (2019) }\end{array}$ & $\begin{array}{l}38 \text { learners in } \\
\text { speaking class } \\
\text { (tertiary) } \\
\text { Indonesia }\end{array}$ & $\begin{array}{l}\text { Learners' speaking skill improved in terms of } \\
\text { fluency, pronunciation and accent, } \\
\text { vocabulary, grammar and details. } \\
\text { Learners' critical thinking skills improved. } \\
\text { MALL is related to constructivist learning } \\
\text { where students construct their own } \\
\text { knowledge through principles such as; active } \\
\text { process, adaptive, contextual, constructive, } \\
\text { personal, social, sense making, experiencing } \\
\text { and comprehending, interaction, and } \\
\text { effective learning. }\end{array}$ \\
\hline 9 & $\begin{array}{l}\text { Nanjundan et } \\
\text { al. (2020) }\end{array}$ & $\begin{array}{l}41 \text { Electrical and } \\
\text { Electronics } \\
\text { Engineering } \\
\text { students } \\
\text { (tertiary) } \\
\text { India }\end{array}$ & $\begin{array}{l}\text { The findings indicate that MALL has improved } \\
\text { all the language skills acquisition by learners. } \\
\text { Websites and apps that involve in language } \\
\text { learning should be encouraged among } \\
\text { learners as they promote self-study and } \\
\text { learner-autonomy. }\end{array}$ \\
\hline
\end{tabular}


Speaking to unknown persons through mobile phone is seen to enhance confidence in speaking.

10 Shamsi et al. 9 participants (6 The results show that MALL has significantly (2019) females and 3 decreased the learners' anxiety in speaking males) English.

(tertiary) The learners have achieved communication

Syria by peers and teachers and decreased fear of language tests.

\begin{tabular}{|c|c|c|c|}
\hline \multirow[t]{2}{*}{11} & \multirow[t]{2}{*}{$\begin{array}{l}\text { Sherine et al. } \\
(2020)\end{array}$} & \multirow{2}{*}{$\begin{array}{l}110 \\
\text { undergraduate } \\
\text { engineering } \\
\text { students } \\
\text { (tertiary) } \\
\text { India }\end{array}$} & $\begin{array}{l}\text { Improvement in speaking skill was indicated } \\
\text { in terms of several aspects such as fluency } \\
\text { and coherence, lexical resource, grammatical } \\
\text { range and accuracy, and pronunciation. }\end{array}$ \\
\hline & & & $\begin{array}{l}\text { Learners have also positively responded } \\
\text { towards the use of Whatsapp and how it } \\
\text { improves their speaking skill on the aspects } \\
\text { mentioned earlier. }\end{array}$ \\
\hline 12 & $\begin{array}{l}\text { Soto and } \\
\text { Zenteno (2019) }\end{array}$ & $\begin{array}{l}317 \text { th grade EFL } \\
\text { learners } \\
\text { (secondary) } \\
\text { South America }\end{array}$ & $\begin{array}{l}\text { The learners' speaking fluency improved in } \\
\text { terms of expression and volume, phrasing, } \\
\text { smoothness, and pace. } \\
\text { The learners have provided positive feedback } \\
\text { on the benefits of video recording on their } \\
\text { speaking fluency and the ease of use. }\end{array}$ \\
\hline 13 & $\begin{array}{l}\text { Tonekaboni } \\
\text { (2019) }\end{array}$ & $\begin{array}{l}60 \text { Iranian EFL } \\
\text { learners at a } \\
\text { Language } \\
\text { Institute } \\
\text { (secondary) } \\
\qquad \\
\quad \text { Iran } \\
\end{array}$ & $\begin{array}{l}\text { Learners who have used the 'English Daily' } \\
\text { mobile app had a significantly better } \\
\text { performance on speaking posttest than the } \\
\text { control group. } \\
\text { The use of the app is positively accepted by } \\
\text { the learners as it maintains their interest and } \\
\text { motivates them. }\end{array}$ \\
\hline 14 & Wan (2019) & $\begin{array}{l}\text { A group of } \\
\text { Chinese EFL } \\
\text { learners } \\
\text { (tertiary) }\end{array}$ & $\begin{array}{l}\text { Generally, the studies done on the use of this } \\
\text { mobile app has yield positive outcomes in } \\
\text { terms of providing rich learning content } \\
\text { anytime and anywhere, realises } \\
\text { communication teaching, and implements } \\
\text { new learning system. }\end{array}$ \\
\hline 15 & Yin (2019) & $\begin{array}{l}86 \text { Chinese EFL } \\
\text { learners from a } \\
\text { civil aviation }\end{array}$ & $\begin{array}{l}\text { Learners improved in speaking skills in the } \\
\text { aspects of pronunciation, accuracy, fluency, } \\
\text { appropriacy and completeness. }\end{array}$ \\
\hline
\end{tabular}


Vol. 10, No. 1, 2021, E-ISSN: 2226-6348 @ 2021 HRMARS

$\begin{array}{ll}\text { vocational } & \text { Learners have provided positive perceptions } \\ \text { college } & \text { on the use of MALL in terms of more } \\ \text { (tertiary) } & \text { engagement in learning, enhanced } \\ \text { China } & \text { motivation, interactive connection, situated } \\ & \text { learning and ease of use. }\end{array}$

The findings are categorised and four main themes were identified to provide answers for the first research question. The themes are discussed as follows.

\section{Applies the Constructivist' Approach}

Generally, most of the reviewed articles suggest that MALL enhances ESL and EFL learners' speaking skills by propagating the concepts of constructivism developed by both Piaget (1968) and Vygotsky (1978). They include collaborative learning, active learning, contextual learning, and authentic learning.

Collaborative Learning. Vygotsky (1978) claimed that learners ultimately benefit from interaction with others to enhance his or her learning achievement through the concept of Zone of Proximal Development (ZPD). The interaction between the learners and more knowledgeable others (MKOs) could effectively aid in developing the learner's skills and strategies. Correspondingly, the findings of the studies indicate that ESL and EFL learners have improved oral communication skills through collaborative learning with their peers and teacher in speaking tasks aided by mobile devices. Kusmaryani et al. (2019) discovered that collaborative learning helped learners involved in their study to improve their speaking skills as they interacted among their peers through dialogues and make sense of meanings. Likewise, learners who recorded their voice during speaking tasks and reviewed the recording for improvement among peers in investigations done by Moghaddas and Bashirnezhad (2016), Darmi and Albion (2017) and Shamsi et al. (2019) have resulted in active construction of knowledge through experience and improved social interaction. Having their speaking errors corrected by peers and teachers who are referred as MKOs have enhanced their speaking skill. Hence, it is crystal clear that MALL could enhance learners' speaking skills through communication and collaboration. This echoes Vygotsky's (1978) idea which claims cognitive functions as the products of social interactions.

Active Learning. Most of the reviewed studies prove that MALL has encouraged active participation among the learners. Learners' speaking skill has tremendously improved as they had opportunities to practice the target language among their peers through pair work and group work. This supports the constructivists' belief that effective learning takes place as learners actively engage and construct meanings in real-world tasks (Piaget, 1968). Study done by Azlan et al. (2019) reported that active learning has stimulated motivation and engagement among preschool and primary school pupils who were the participants of the study. Prior to the implementation of MALL, they were noted to have poor level of English proficiency and low or no motivation towards learning English. The infusion of face-filter interface from Instagram while recording their speaking performances has boosted their motivation and enhanced their speaking skill simultaneously. Active learning ultimately allows learners to explore learning and develop language skills by themselves which is oppose to teacher-centered learning in which learners receive knowledge passively. This has been clearly illustrated in a study done by Yin 
(2019) among the Chinese learners where MALL has allowed them to take control of their learning through active learning and resulted in having high motivation and more engagement in parallel to findings reported by Azlan et al. (2019). At this point, active engagement among learners is viewed essential in enhancing learners' speaking skills and MALL makes it possible.

Contextual Learning. Contextual learning allows learners to process new information or knowledge in such a way that it makes sense to them in their own frames of reference. This normally occurs as learners perform 'bridging' in making abstractions from their contextualised experience (Sharples, 2018). This is evident in Almarshadi et al. (2019) and Kusmaryani et al. (2019) that using features of a smart phone such as dictionary, videos, audios, and other authentic applications aid in providing contextual learning that accelerates learners' oral comprehension, fluency, pronunciation, vocabulary, grammar accuracy and accent. Learners are detected to comprehend knowledge better as they practice speaking in various contexts (Kusmaryani et al., 2019). As proclaimed by Klopfer et al. (2002), mobile devices are context sensitive and therefore they could provide learners with rich learning context beyond classroom. MALL efficiently allows learners to practice speaking the target language by applying words, phrases, and structures learned in formal classroom in informal contexts.

Authentic Learning. The teaching of speaking has taken a great shift from focusing on linguistic abilities to communicate competence (James et al., 2019). According to Freeman and Anderson (2011), communicative language teaching focuses on providing authentic use of language which depicts the real-world situations with the help of authentic materials and speaking activities. In accordance to this, the use of mobile devices is believed to have better access towards authentic learning materials which are regarded helpful in developing ESL learners' speaking skill. Supporting this, a survey conducted by Abugohar et al. (2019) reflected that a group of EFL teachers working in higher education institutions in Saudi Arabia perceive smart phone applications as good source of authentic materials which provide content beyond of what being learned in the classroom and 'friendly' for shy and anxious ESL learners. The use of such materials has given positive impact towards improving their fluency, accuracy, and confidence. Another study done by Gonulal (2019) adds that the use of Instagram as authentic platform in MALL serves as a bridge between formal and informal learning. This is also apparent in Sherine et al. (2020) whereby learners were exposed to speaking activities both inside and outside the classroom using Whatsapp. The authenticity provided in MALL environment does not only make learning authentic, but it also complements the contextual learning experiences as discussed earlier (Almarshadi et al., 2019; Kusmaryani et al., 2019).

\section{Provides a stress-free environment}

Dull and tense environment can impede pupils' interest in language learning. From the review, MALL has been proven to improve ESL and EFL learners' speaking skills by providing a lively and fun environment for the practice of speaking the target language (Azlan et al., 2019) which is less stressful. Besides, in a study done by Tonekaboni (2019), the use of English Daily mobile app has maintained the learners' interest to continue speaking through various speaking tasks and is perceived to be a motivational tool. Sun et al. (2017) noticed that participants in the experimental group who used SNS through mobile devices gained higher speaking fluency than the control group as they were able to speak in an environment with reduced stress. The use of 
mobile applications by language teachers in a study done by Abugohar et al. (2019) has also been helpful in reducing the anxiety level of shy learners to speak in less stressful and less fearful environment that eventually resulted in having better fluency, accuracy, and confidence. Speaking activities done via social media accessed through smart phones has equally decreased learners' anxiety in speaking English, fear of receiving feedback from teacher and peers as well as fear of taking language tests (Shamsi et al., 2019). Having said that, MALL appears to be one among the suitable approaches to be applied for encouraging shy, timid, and anxious learners to speak the target language.

\section{Supports Situated Learning}

According to Greeno (1997), situated learning occurs in multifaceted social environments whereby learners learn though independency. This theory is deemed appropriate in the context of MALL. This is because with MALL is believed to be expose rich learning content anytime, and anywhere without the dependency on the teacher and substantially proven through several studies (Sun et al., 2017; Wan, 2019; Yin, 2019). The concept of learning anytime, and anywhere has further resulted in autonomous learning by promoting responsibility among ESL learners. Wan (2019) asserts that this implements a new learning system in which it explores the self-study concept (Nanjundan et al., 2020). Hence, the use of MALL can be regarded as a great platform in allowing learners to practice speaking in the target language without having to be physically present in the language classroom. They can perform speaking activities from wherever they are at their own pace.

\section{Ease of Use}

Technology Acceptance Model or TAM was developed to predict and identify how an individual perceives the use of technology (Venkatesh \& Bala, 2008). In this model, there are five constructs known as the perceived ease of use (PEOU), perceived usefulness (PU), attitude towards using (ATU), behavioural intention (BI) and actual use. According to Davis (1989), perceived usefulness is defined as "the degree to which an individual believes that using a particular system would enhance his or her productivity". The more extent the usefulness, the more adopted the IT. On the other hand, perceived ease of use is defined as "the degree an individual believes that using a particular system would be free of effort". The easier the use, the more accepted the IT. The recognition affected the attitudes and furthered the behaviours. Thus, TAM was employed to elucidate and predicate the acceptance of use of IT in which the use intention and behaviour of individuals were affected by two key variables which are perceived usefulness and perceived ease of use.

Based on the review done in this study, several studies indicated that ESL learners' speaking skills have tremendously improved as they perceive the use of MALL as being easy and user-friendly. With this perception, their attitude towards the use of mobile devices was positive which further motivated them to use it for developing their speaking skill. For instance, the use of Papa SNS in a study conducted by Sun et al. (2017) is regarded to be user-friendly and the first grade Chinese EFL learners were able to use the SNS by themselves without requiring great effort. Yin's (2019) findings manifested a group of Chinese EFL learners having improved in in terms of speaking skill as they perceived the use of mobile built-in features as easy and convenient. Apart 
from that, a study done among EFL learners aged between 12 to 13 years old in South America by Soto and Zenteno (2019) yielded similar results. The learners reported the use of video recording to record and review their speaking presentations as being easy. Therefore, MALL could be regarded as one of the feasible ways to have learners' speaking skills enhanced without hassles and much effort.

RQ2: What are the potential mobile device tools that could be used in enhancing speaking skills among ESL and EFL learners?

As for the second research question, the articles were reviewed in terms of mobile device tools used by researchers as well as educators in the teaching and learning of speaking skills in MALL among ESL and EFL learners. The reviews are as elaborated in Table 5 below.

Table 5. Summary on the mobile device tools used in the studies reviewed

\begin{tabular}{|c|c|c|}
\hline No & Article/ Study & Mobile device tools used \\
\hline 1 & $\begin{array}{l}\text { Moghaddas and } \\
\text { Bashirnezhad } \\
(2016)\end{array}$ & $\begin{array}{l}\text { Learners' voices were recorded using audio recording feature in } \\
\text { mobile phone and played back for review. }\end{array}$ \\
\hline 2 & $\begin{array}{l}\text { Darmi and } \\
\text { Albion (2017) }\end{array}$ & $\begin{array}{l}\text { Learners used the audio/video recording in built features to } \\
\text { record their classroom speaking tasks such as interviews and } \\
\text { review for improvement. }\end{array}$ \\
\hline 3 & $\begin{array}{l}\text { Sun et al. } \\
(2017)\end{array}$ & Papa SNS accessed via mobile devices \\
\hline 4 & $\begin{array}{l}\text { Abugohar et al. } \\
\text { (2019) }\end{array}$ & $\begin{array}{l}\text { Speech-to-text transcription applications- Voice Recognition } \\
\text { Software, Speech texter, Speechnotes, Voice Notebook, and } \\
\text { Speech to Text Converter } \\
\text { Audio recording animation-based applications -Virtual Speaking } \\
\text { Buddy, Talking Tom, Voki, Talking Angela, Second Life and English } \\
\text { Speaking Buddy } \\
\text { 5Automatic speech analysis video applications- English Central, } \\
\text { and Tell Me More. }\end{array}$ \\
\hline 5 & $\begin{array}{l}\text { Almarshadi et } \\
\text { al. (2019) }\end{array}$ & $\begin{array}{l}\text { In built features- dictionary } \\
\text { Mobile applications on authentic resources- videos, audios } \\
\text { SNSs- Whatsapp, emails }\end{array}$ \\
\hline 6 & $\begin{array}{l}\text { Azlan et al. } \\
\text { (2019) }\end{array}$ & $\begin{array}{l}\text { Social media- Instagram } \\
\text { Learners were required to do task-based speaking performance } \\
\text { either in pairs or groups. A few types of face-filter interface from } \\
\text { Instagram's features were applied while recording their } \\
\text { performances. The recordings were uploaded in Instagram and } \\
\text { sent to parents to get feedback from them and other peers. }\end{array}$ \\
\hline 7 & Gonulal (2019) & Social media- Instagram platform \\
\hline 8 & $\begin{array}{l}\text { Kusmaryani et } \\
\text { al. (2019) }\end{array}$ & $\begin{array}{l}\text { Mobile applications for critical thinking- online dictionary, } \\
\text { language translator, speaking English, English grammar, speech to } \\
\text { text. }\end{array}$ \\
\hline
\end{tabular}




\begin{tabular}{|c|c|c|}
\hline & & $\begin{array}{l}\text { Mobile applications on authentic learning sources- Whatsapp, } \\
\text { Google Chrome, YouTube, Weebly, and Gmail. }\end{array}$ \\
\hline 9 & $\begin{array}{l}\text { Nanjundan et } \\
\text { al. (2020) }\end{array}$ & $\begin{array}{l}\text { Websites for speaking skill- fluentu.com, myenglishteacher.eu } \\
\text { Apps for speaking skill- English podcast, and Learn English, Speak } \\
\text { English- Conversation } \\
\text { Each participant must mandatorily speak to toll free customer } \\
\text { care no and continue their speech for five minutes through mobile } \\
\text { phone }\end{array}$ \\
\hline 10 & $\begin{array}{l}\text { Shamsi et al. } \\
\text { (2019) }\end{array}$ & $\begin{array}{l}\text { Social media- Whatsapp } \\
\text { Learners recorded their voice during speaking tasks and send the } \\
\text { recordings to Whatsapp group. They then received feedback } \\
\text { about their strengths and weaknesses in their performance in } \\
\text { terms of grammar, pronunciation, vocabulary, and fluency. }\end{array}$ \\
\hline 11 & $\begin{array}{l}\text { Sherine et al. } \\
(2020)\end{array}$ & $\begin{array}{l}\text { SNS- Whatsapp } \\
\text { A variety of speaking activities were given to learners for both } \\
\text { informal and formal learning. They were done both synchronously } \\
\text { and asynchronously. }\end{array}$ \\
\hline 12 & $\begin{array}{l}\text { Soto and } \\
\text { Zenteno (2019) }\end{array}$ & $\begin{array}{l}\text { Learners were encouraged to speak in English and record their } \\
\text { presentations using smart } \\
\text { phone video recording apps and pass the recordings to their } \\
\text { teacher via e-mail or pen drive. }\end{array}$ \\
\hline 13 & $\begin{array}{l}\text { Tonekaboni } \\
\text { (2019) }\end{array}$ & $\begin{array}{l}\text { The learners listened to the words or phrases and repeated them } \\
\text { chorally and their voices were recorded by the English Daily app } \\
\text { and played for them. They also listened to their individual } \\
\text { speaking which was recorded by the software and compared } \\
\text { themselves to a native speaker. }\end{array}$ \\
\hline 14 & Wan (2019) & English Fluent Mobile App \\
\hline 15 & Yin (2019) & $\begin{array}{l}\text { Collaborative tasks were assigned using various in built features in } \\
\text { mobile devices such as smart phones, iPads and tablets. }\end{array}$ \\
\hline
\end{tabular}

Review on the use of mobile device tools for enhancing speaking skills among ESL and EFL learners has resulted in two major themes. These themes are further discussed.

\section{The use of general built-in features}

Among the 15 articles reviewed, five studies were done with the base of using readily built-in features of mobile devices as tools for conducting speaking tasks. Studies done by Moghaddas and Bashirnezhad (2016), Darmi and Albion (2017), Yin (2019) and Soto and Zenteno (2019) proven that audio and video recording features of mobile phones have aided the ESL and EFL learners to record their voice during speaking presentations and play them to review the mistakes done with their teacher and peers. These features were also deemed to provide quick and easy access to the learners (Soto \& Zenteno, 2019). The effectiveness of using the audio and video recordings was apparent among the participants of the experimental group whereby they significantly outperformed the control group in terms of speaking fluency. Besides, the 
participants involved in Almarshadi et al.'s (2019) survey found that the use of dictionary feature of the smart phone as being helpful in learning correct pronunciation of English words, lexical items and grammar accuracy which subsequently improves their speaking skill. At this point, it is made clear that educators could make use of readily built-in features of a mobile phone as a tool for the teaching and learning of speaking.

\section{The use of Mobile Applications (English learning apps and SNSs)}

A mobile app is similar to a computer program. It is specifically designed to run on mobile phones, tablet computers (like tabs and iPads) and other mobile devices. "App" is the shortening of the term "application software". Apps are easily available through application distribution platform called App Market, and these apps are typically operated by the owner of the mobile operating system, such as the Apple App Store, Google Play, Windows Phone Store, and BlackBerry App World. There are two main app stores: Google Play for Android and Apple App Store for iOS. Most of the apps available in platforms mentioned above can be downloaded by users freely, while some require purchasing. These apps can be both downloaded in smart phones or to computers. Currently, there are plenty of English learning apps available in the app stores and this has triggered the interests of educators to apply these apps in language learning.

Mobile apps have also proven beneficial in the context of developing speaking skill among ESL and EFL learners. The findings of this review reveal that Tonekaboni's (2019) 46 EFL elementary participants from Iran were found to have benefited the use of 'English Daily' mobile app. They were performing significantly better than those control group participants in the speaking post-test. A survey done by Abugohar et al. (2019) concluded that $49 \mathrm{EFL}$ teachers working in higher education institutions in Saudi Arabia have high positive perceptions on the use of mobile apps such as 'Talking Tom', 'Virtual Speaking Buddy', 'Voki' and 'Talking Angela' for teaching speaking, however, classroom practices reveal weaknesses and insufficient actual practices. Similarly, an empirical analysis done by Wan (2019) among colleges in China proves that 'English Fluent' app has positively impacted the learners by realising communication teaching settings. Compounding this, Nanjundan et al. (2020) emphasised that the use of mobile apps such as 'English podcast', and 'Learn English, Speak English' should be encouraged among ESL and EFL learners as they can promote self-study concept thus resulting in autonomous learning.

Gupta and Bashir (2018) explain that the use of SNSs means online space for students to interact, chat, or maintain ties for education, entertainment, socialization, and other purposes. Besides Facebook and Twitter, Instagram and Whatsapp are also most preferred by the users since there has been rapid emergence of different channels (Azlan \& Yunus, 2020). The friendly and interactive interference from the website and applications has attracted the users to use it for various reasons in their daily activities (Azlan \& Yunus, 2020). Supporting this, Sun et al. (2017) claimed that the acquisition of speaking skill among ESL and EFL learners can be done effectively using various social networking sites. In this review, it is noticed that the most popular social networking platform preferred by ESL and EFL learners to practice speaking is via Whatsapp (Almarshadi et al., 2019; Kusmaryani et al., 2019; Shamsi et al., 2019; Sherine et al., 2020). In all these studies, learners were seen to be comfortable in recording their speaking task and sharing it among their peers and teacher via Whatsapp. It is regarded to support communication and 
build confidence in expressing their thoughts (Almarshadi et al., 2019). Furthermore, expressing thoughts in Whatsapp is believed to be less stressful (Shamsi et al., 2019). On the other hand, Instagram is also perceived to be a great platform in creating lively environment and developing a strong collaboration as well as active interaction among learners and teacher (Azlan et al., 2019).

\section{Discussions}

This section summarises the key aspects found in the findings and discusses them in relation to previous literatures.

Previous studies highlighted on the elements of MALL that have significantly impacted the acquisition of speaking skills among ESL and EFL learners from different parts of the world. Several studies were based on the local Malaysian context and others were done in countries which regard English as a 'second' or 'foreign' language such as Iran, China, South America, Indonesia, Syria, Saudi Arabia and India.

Generally, the studies' findings reported that the use of MALL has impacted the learners positively in terms of their speaking skills. As mentioned earlier, the basis of learning through mobile device features is believed to apply the principles of constructivism theory developed by Piaget (1968) and Vygotsky (1978). The learning has apparently infused the element of Zone of Proximal Development (ZPD) by collaborative learning whereby learners constructed knowledge through experience and sharing with the 'more knowledgeable others' such as the peers and teacher. This scenario is depicted through several studies in which learners were involved in speaking tasks that required them to record their presentations and review them in groups (Moghaddas \& Bashirnezhad, 2016; Darmi \& Albion, 2017; Kusmaryani et al., 2019; Shamsi et al., 2019). Next, the use of MALL has also promoted active learning among the learners. Learners were provided ample time and opportunities to produce comprehensible input in the target language and teacher's role was to be a facilitator (Azlan et al., 2019; Yin, 2019). In addition, the inculcation of contextual learning was also equally evident in few studies such as in Kusmaryani et al. (2019) and Almarshadi et al. (2019). In both studies, the improvement of speaking skills among learners was a result of learners being able to learn the structures in context. The contexts used in the mobile device features were perceived to be personalised and relevant in linking to their experiences. Being the most indicated element in the studies, the access to authentic materials through audios and videos in mobile devices further complements contextual learning experiences among learners (Abugohar et al., 2019; Almarshadi et al., 2019; Gonulal, 2019; Kusmaryani et al., 2019; Sherine et al., 2020).

Moving further, MALL has provided a conducive atmosphere for learners to express their thoughts via speaking activities without stress and fear of being judged (Sun et al., 2017; Abugohar et al., 2019; Azlan et al., 2019; Shamsi et al., 2019). Learning was observed to happen in a lively and stress-free manner with the use of mobile features. Nevertheless, the use of MALL has supported the theory of situated learning whereby it offers learners with seamless learning experience that makes learning possible anytime and anywhere. Studies reviewed (Sun et al., 2017; Wan, 2019; Yin, 2019; Nanjundan et al., 2020) proved that learners were able to participate in speaking activities without being limited to the classroom setting. Learning took place actively inside as well as outside the classroom contexts. Finally, the use of mobile devices as a tool for 
learning is considerably convenient and easy (Soto \& Zenteno, 2019; Yin, 2019). The perceived ease of use of the users is expected to augment their attitudes towards using mobile features for learning.

As for the second part of the review, mobile device tools that can be effectively used by both educators and learners to upscale speaking skills in ESL and EFL contexts were identified. The review suggests that general built-in features of mobile devices such as audio and video recording can be efficiently used in improving learners' speaking skill (Moghaddas \& Bashirnezhad, 2016; Darmi \& Albion, 2017; Yin, 2019, Soto \& Zenteno, 2019). Additionally, the use of dictionary feature in smart phone is also reported useful in learning words, phrases and grammar structures which leads towards accuracy in speaking (Almarshadi et al., 2019). Apart from that, studies done using mobile applications including English learning mobile apps (Abugohar et al., 2019; Tonekaboni, 2019; Wan, 2019; Nanjundan et al., 2020) and SNSs such as Whatsapp and Instagram (Almarshadi et al., 2019; Kusmaryani et al., 2019; Shamsi et al., 2019; Sherine et al., 2020) featured them as being practical and feasible to be used as tools for practicing speaking among learners.

\section{Conclusion}

This systematic literature review demonstrates that the use of MALL among ESL and EFL learners has tremendously impacted their acquisition of speaking skills. The studies reviewed implied that MALL applies pedagogical approaches which are underpinned by the principles of constructivism theory, provides stress-free environment for learning, supports situated learning, and provides ease of use. Additionally, the affordances of mobile device tools such as mobile phone built-in features and mobile apps are regarded to be highly potential in enhancing learners' speaking skills. These findings propose that educators worldwide especially those teaching in ESL and EFL contexts could consider applying MALL in the teaching and learning of speaking for promising results.

The current systematic review has explored the use of MALL for enhancing speaking skills among ESL and EFL learners by systematically reviewing 15 articles regarded appropriate based on the inclusion criteria. Due to time limitation, only two databases namely ERIC and Google Scholar were used to search for the articles. Future researchers could extend the results by sourcing from other databases or printed documents. Most of the studies reviewed have attempted to show the impact of MALL on speaking in tertiary education, however, there is a need for investigating the integration of MALL in primary and secondary schools. Besides, challenges faced by both educators and learners in MALL need further emphasis so that the constraints of MALL could be highlighted. Additionally, the focus of the reviewed studies was mostly on the use of smartphone and has left the use of tablets almost unexplored. Therefore, future studies could gear towards fulfilling the gap in the technological aspect of MALL.

MALL environments particularly for speaking skills is an area that still needs to be studied. Further studies with the consideration of the above suggestions are believed to yield richer outcomes. It is hoped that the findings of this systematic literature review would aspire ESL and EFL educators to transform instructional activities involving the teaching of speaking skill to be more creative and innovative with the incorporation of MALL. Policy makers, on the other side, 
INTERNATIONAL JOURNAL OF ACADEMIC RESEARCH IN PROGRESSIVE EDUCATION AND

DEVELOPMENT

Vol. 10, No. 1, 2021, E-ISSN: 2226-6348 @ 2021 HRMARS

are expected to consider infusing the element of MALL in designing educational policies so that MALL could be efficiently infused in the mainstream teaching.

\section{References}

Abugohar, M. A., Rashid, R. A. \& Yunus, K. (2019). Smartphone Applications as a Teaching Technique for Enhancing Tertiary Learners' Speaking Skills: Perceptions and Practices. International Journal of Emerging Technologies in Learning (iJET) , 74-92. doi: 10.3991/ijet.v14i09.10375

Ali, M. M., Mahmood, M. A., Anwar, M. N., Khan, L. A., \& Hussain, A. (2019). Pakistani Learners' Perceptions Regarding Mobile Assisted Language Learning in ESL Classroom. International Journal of English Linguistics, 9(4):386-398. doi: 10.5539/ijel.v9n4p386

Almarshadi, A. N., Alenazi, S. N., Bidin, A., AbdulKarim, A.\& Nasir, M. K. (2019). The Application of M-Learning in Improving Speaking Skills among EFL Learners. ResearcherID, 6(8):1-16.

Azlan, N. A. B., Zakaria, S. B., \& Yunus, M. M. (2019). Integrative Task-Based Learning: Developing Speaking Skill and Increase Motivation via Instagram. International Journal of Academic Research in Business and Social Sciences, 9(1):620-636. doi: 10.6007/IJARBSS/v9-i1/5463

Azli, W. U. A. W., Shah, P. M., \& Mohamad, M. (2018). Perception on the usage of mobile assisted language learning (MALL) in English as a second language (ESL) learning among vocational college students. Creative Education, 9(01):84. doi: 10.4236/ce.2018.91008

Bailey, K. M., \& Savage, L. (1994). New Ways in Teaching Speaking. New Ways in TESOL Series:Innovative Classroom Techniques. TESOL, 1600 Cameron Street, Suite 300, Alexandria, VA 22314.

Brown, H. D. (2001). Teaching by Principles: an Interactive Approach to Language. New York: Addison Wesley Longman, inc.

Burkart, G., \& Sheppard, K. (2004). Content-ESL across the USA: A training packet. A descriptive. Burston, J. (2015). Review of mobile learning: Languages, literacies, and cultures.

Chung, H. H., Chen, S. C., \& Kuo, M. H. (2015). A study of EFL college students' acceptance of mobile learning. Procedia-Social and Behavioral Sciences, 176, 333-339.

Darmi, R. \& Albion, P. (2017). Enhancing oral communication skills using mobile phones among undergraduate English language learners in Malaysia. Springer, 1-14. doi: 10.1007/978981-10-4944-6_15

Davis, F. D. (1989). User Acceptance of Information Technology: System Characteristics, User Perceptions and Behavioral Impacts. International Journal of Man-Machine Studies, 38:475-487. doi: 10.1006/imms.1993.1022

Foomani, E. M., \& Hedayati, M. (2016). A seamless learning design for mobile assisted language learning: An Iranian context. English Language Teaching, 9(5):206-213.

Freeman, D. L., \& Anderson, M. (2011). Techniques \& Principles in Language Teaching. New York: Oxford.

Gamble, C. (2018). Exploring EFL university students' acceptance of e-learning using TAM. Kwansei Gakuin University Humanities Review, 22, 23-37.

Gonulal, T. (2019). The Use of Instagram as a Mobile-Assisted Language Learning Tool. Contemporary Educational Technology, 10(3):309-323. doi: 10.30935/cet.590108 
Greeno, J. G. (1997). On claims that answer the wrong questions. Educational researcher, 26(1):517.

Gupta, S., \& Bashir, L. (2018). Social networking usage questionnaire: Development and validation in an Indian higher education context. Turkish Online Journal of Distance Education, 19(4):214-227.

Harris, D. P. (1969). Testing English as a second Language. McGraw-Hill.

Hashim, H., Yunus, M. M., \& Embi, M. A. (2017). Does Language Learning Potential Affects ESL Learners' Attitude Towards Mobile Learning?

Hashim, H., Yunus, M. M., Embi, M. A., \& Ozir, N. A. M. (2017). Mobile-assisted Language Learning (MALL) for ESL Learners: A Review of Affordances and Constraints. Sains Humanika, 45-50. doi: 10.11113/sh.v9n1-5.1175

Hsieh, J. S. C., Huang, Y. M., \& Wu, W. C. V. (2017). Technological acceptance of LINE in flipped EFL oral training. Computers in Human Behavior, 70, 178-190.

James, P. R. A. P., Yong, K. L., \& Yunus, M. M. (2019). Hear Me Out! Digital Storytelling to Enhance Speaking Skills. International Journal of Academic Research in Business and Social Sciences, 9(2): 190-202. doi: 10.6007/IJARBSS/v9-i2/5533

John, D. S., \& Yunus, M. M. (2019). Students' Perceptions on the Use of Mobile Learning to Improve Writing Proficiency in the MUET. Pertanika Journal of Social Sciences \& Humanities, 27 (3):1481 - 1492.

Kaliisa, R., \& Picard, M. . (2017). A systematic review on mobile learning in higher education: The African perspective. Turkish Online Journal of Educational Technology-TOJET, 16(1):1-18.

Khan, K. S., Kunz, R., Kleijnen, J., \& Antes, G. (2003). Five steps to conducting a systematic review. Journal of the Royal Society of Medicine. doi: 10.1258/jrsm.96.3.118

Khan, M. M., \& Islam, M. (2019). Tertiary Level Students' attitude towards the use of Mobile Assisted Language Learning (MALL).

Klopfer, E., Squire, K., \& Jenkins, H. 2002. Environmental Detectives: PDAs as a Window Into A Virtual Simulaed World. Proceedings for IEEE International Workshop on Wireless and Mobile Technologies in Education, 95-98.

Krashen, S. D. (1988). Second Language Acquisition and Second Language Learning. New York: Prentice-Hall.

Kukulska-Hulme, A., \& Shield, L. (2008). An overview of mobile assisted language learning: From content delivery to supported collaboration and interaction. ReCALL, 20(3), 271-289.

Kukulska-Hulme, A. (2009). Will mobile learning change language learning? ReCALL, 21(2):157165.

Kukulska-Hulme, A., Lee, H., \& Norris, L. (2017). Mobile learning revolution: Implications for language pedagogy. The handbook of technology and second language teaching and learning, 217-233.

Kusmaryani, W., Musthafa, B. \& Purnawarman, P. (2019). The influence of mobile applications on students' speaking skill and critical thinking in English language learning. International Conference of Computer and Informatics Engineering (IC2IE), 1-6. doi:10.1088/17426596/1193/1/012008

Leong, L.-M., \& Ahmadi, S. M. (2017). An Analysis of Factors Influencing Learners' English Speaking Skill. International Journal of Research in English Education, 34-41. 
Lie, W. W., \& Yunus, M. M. (2018). Pen Pals Are Now in Your Finger Tips-A Global Collaboration Online Project to Develop Writing Skills. Creative Education, 9(15):2491. doi: 10.4236/ce.2018.915188

Liu, Q., \& He, X. (2014). Using Mobile Apps to Facilitate English Learning For College Students in China. Sweden: University Of Boras.

Lucanus, A. (2017). Oral Communication Skills Are Important for Students. Retrieved from The College Puzzle: https://collegepuzzle.stanford.edu/oral-communication-skills-areimportant-for-students/

Moghaddas, B., \& Bashirnezhad, H. (2016). The Pedagogical Applications of Mobile-Assisted Language Learning (MALL) in Improving the Iranian EFL Learners' Oral Performance. International Journal of Applied Linguistics and Translation, 2(1):8-14. doi: 10.11648/j.ijalt.20160201.12

Nanjundan, V., Senthilkumar, S., Jayasudha, T., \& Sankar, G. (2020). Adoption of M-Learning to Enhance LSRW Skills For Learners of English as a Second Language. Journal of Xi'an University of Architecture \& Technology, 2596-2612.

Nunan, D. 1999. Second Language Teaching and Learning. Boston: Heinle \& Heinle Publishers

Octavia, H., Widiati, U., \& Irawati, E. (2019). Vocational Students' Perceptions of Mobile Assisted Language Learning (MALL) Materials. Jurnal Pendidikan: Teori, Penelitian, dan Pengembangan, 4(10):1347-1352. doi: 10.17977/jptpp.v4i10.12842

Paneerselvam, A., \& Mohamad, M. (2019). Learners' Challenges and English Educators' Approaches in Teaching Speaking Skills in an ESL Classroom: A Literature Review. Creative Education, (10): 3299-3305. doi: 10.4236/ce.2019.1013253

Pearson, A., White, H., Bath-Hextall, F., Salmond, S., Apostolo, J.\& Kirkpatrick, P. (2015). A mixedmethods approach to systematic reviews. International Journal of Evidence-Based Healthcare, 13(3):121-131.

Persson, V., \& Nouri, J. (2018). A systematic review of second language learning with mobile technologies. International Journal of Emerging Technologies in Learning (iJET), 13(02), 188-210.

Piaget, J. 1968. Six Psychological Studies. New York: Vintage Books.

Rahamat, R., M.Shah, P., Din, R., Abd Aziz, J. (2017). Students' Readiness and Perceptions Towards Using Mobile Technologies For Learning the English Language Literature Component. The English Teacher, 69-84.

Rao, P. S. (2019). The Role of English as a Global Language. Research Journal of English , 4(1):6579.

Reinders, H. (2010). Twenty ideas for using mobile phones in the language classroom. 20-33.

Richards, J. (2008). Teaching Listening and Speaking from theory to practice. New York: Cambridge University.

Shamsi, A. F., Altaha, S., \& Gilanlioglu, I. (2019). The Role of M-Learning in Decreasing Speaking Anxiety for EFL Learners. Online Submission, 2(1):276-282. doi: 10.32996/ijllt.2019.2.1.34

Sharples, M. (2018). Making sense of context for mobile learning. J. Traxler \& A. Kukulska-Hulme (Eds.), Mobile Learning: The Next Generation, 140-153. 
Sherine, A., \& Seshagiri, A. V. S. (2020). Impact of WhatsApp Interaction on Improving L2 Speaking Skills. International Journal of Emerging Technologies in Learning (iJET), 15(3):250-259. doi: 10.3991/ijet.v15i03.11534

Soto, C. P., \& Zenteno, C. C. (2019). Smartphone screen recording apps: an effective tool to enhance fluency in the English language. Colombian Applied Linguistics Journal, 21(2). doi: $10.14483 / 22487085.14202$

Soleimani, E., Ismail, K., \& Mustaffa, R. (2014). The acceptance of mobile assisted language learning (MALL) among post graduate ESL students in UKM. Procedia-Social and Behavioral Sciences, 118(1), 457-462.

Sun, Z., Lin, C. H., You, J., Shen, H. J., Qi, S., \& Luo, L. (2017). Improving the English-speaking skills of young learners through mobile social networking. Computer Assisted Language Learning, 30:304-324. doi: 10.1080/09588221.2017.1308384

Sung, Y. T., Chang, K. E., \& Liu, T. C. (2016). The effects of integrating mobile devices with teaching and learning on students' learning performance: A meta-analysis and research synthesis. Computers \& Education, 94, 252-275.

Supti, F. K. (2019). The impact of Mobile Assisted Language Learning (MALL) on ESL learners' language skills: a study of tertiary level students (Doctoral dissertation, Brac University).

The Joanna Briggs Institute . (2014). Methodology for JBI Mixed Methods Systematic Reviews. Reviewers Manual.

Tonekaboni, A. M. (2019). Effects of Mobile Assisted Language Learning (MALL) on Speaking Proficiency (A case of Learn English Daily Mobile App). 2nd International Conference on Advanced Research in Humanities and Art, (pp. 1-13). Venice, Italy.

Traxler, J. (2007). International review of research in open and distance learning: Defining, discussing, and evaluating mobile learning:The moving finger writes and having writ... $8(2): 1-12$.

Traxler, J., \& Kukulska-Hulme, A. (2015). Introduction to the next generation of mobile learning. In Mobile Learning (pp. 1-10). Routledge.

Traxler, J., \& Kukulska-Hulme, A. (2016). Contextual challenges for the next generation. Mobile learning: The next generation, 208-226.

Venkatesh, V., \& Bala, H. (2008). Technology Acceptance Model 3 and a Research Agenda on Interventions. Decision Sciences, 39(2):273-315.

Vygotsky, L. S. (1978). Mind in Society. Cambridge: MA: MIT Press.

Wan, L. (2019). The Application Research of Mobile Learning App" English Fluency" in College English Oral Teaching. doi: 10.25236/etmhs.2019.008

Yin, S. (2019). An Empirical Study on Improving Speaking Skills of Students in Vocational Colleges Under MALL Environments. International Conference on Computation and Information Sciences (ICCIS 2019), 777-784. doi: 10.12783/dtcse/iccis2019/31975

Zakaria, M. I., Maat, S. M., \& Khalid, F. (2019). A Systematic Review of M-learning in Formal Education. International Journal of Innovation, Creativity and Change, 7(11): 1-24. 